University of Nebraska - Lincoln

DigitalCommons@University of Nebraska - Lincoln

2006

Comparison of Feed Energy Costs of Maintenance, Lean Deposition, and Fat Deposition in Three Lines of Mice Selected for Heat Loss

D. L. Eggert

University of Nebraska-Lincoln

Merlyn K. Nielsen

University of Nebraska-Lincoln, mnielsen1@unl.edu

Follow this and additional works at: https://digitalcommons.unl.edu/animalscifacpub

Part of the Animal Sciences Commons

Eggert, D. L. and Nielsen, Merlyn K., "Comparison of Feed Energy Costs of Maintenance, Lean Deposition, and Fat Deposition in Three Lines of Mice Selected for Heat Loss" (2006). Faculty Papers and Publications in Animal Science. 513.

https://digitalcommons.unl.edu/animalscifacpub/513

This Article is brought to you for free and open access by the Animal Science Department at DigitalCommons@University of Nebraska - Lincoln. It has been accepted for inclusion in Faculty Papers and Publications in Animal Science by an authorized administrator of DigitalCommons@University of Nebraska - Lincoln. 


\title{
Comparison of feed energy costs of maintenance, lean deposition, and fat deposition in three lines of mice selected for heat loss ${ }^{1}$
}

\author{
D. L. Eggert and M. K. Nielsen ${ }^{2}$ \\ Department of Animal Science, University of Nebraska, Lincoln 68583-0908
}

\begin{abstract}
Three replications of mouse selection populations for high heat loss (MH), low heat loss (ML), and a nonselected control (MC) were used to estimate the feed energy costs of maintenance and gain and to test whether selection had changed these costs. At 21 and $49 \mathrm{~d}$ of age, mice were weighed and subjected to dual x-ray densitometry measurement for prediction of body composition. At $21 \mathrm{~d}$, mice were randomly assigned to an ad libitum, an $80 \%$ of ad libitum, or a $60 \%$ of ad libitum feeding group for 28-d collection of individual feed intake. Data were analyzed using 3 approaches. The first approach was an attempt to partition energy intake between costs for maintenance, fat deposition, and lean deposition for each replicate, sex, and line by multiple regression of feed intake on the sum of daily metabolic weight $\left(\mathrm{kg}^{0.75}\right)$, fat gain, and lean gain. Approach II was a less restrictive attempt to partition energy intake between costs for maintenance and total gain for each replicate, sex, and line by multiple regression of feed intake on the sum of daily metabolic weight and total gain. Approach III used multiple regression on the entire data set with pooled regressions on fat and lean gains, and subclass regressions for maintenance.
\end{abstract}

Contrasts were conducted to test the effect of selection $(\mathrm{MH}-\mathrm{ML})$ and asymmetry of selection $[(\mathrm{MH}+\mathrm{ML}) / 2$ $-\mathrm{MC}$ ] for the various energy costs. In approach I, there were no differences between lines for costs of maintenance, fat deposition, or protein deposition, but we question our ability to estimate these accurately. In approach II, selection changed both cost of maintenance $(P=0.03)$ and gain $(P=0.05)$; $\mathrm{MH}$ mice had greater per unit costs than ML mice for both. Asymmetry of the selection response was found in approach II for the cost of maintenance $(P=0.06)$. In approach III, the effect of selection $(P<0.01)$ contributed to differences in the maintenance cost, but asymmetry of selection $(P$ $>0.17$ ) was not evident. Sex effects were found for the cost of fat deposition $(P=0.02)$ in approach I and the cost of gain $(P=0.001)$ in approach II; females had a greater cost per unit than males. When costs per unit of fat and per unit of lean gain were assumed to be the same for both sexes (approach III), females had a somewhat greater estimate for maintenance $\operatorname{cost}(P=$ 0.10 ). We conclude that selection for heat loss has changed the costs for maintenance per unit size but probably not the costs for gain.

Key words: fat deposition energy, lean deposition energy, maintenance energy, mice, selection

(C2006 American Society of Animal Science. All rights reserved.

J. Anim. Sci. 2006. 84:276-282

\section{INTRODUCTION}

Improvement in the efficiency of feed energy use by livestock might be realized through any or a combination of the following: 1) lower maintenance energy cost per unit of body size; 2 ) lower energy cost above maintenance per unit of product produced; or 3) greater product output per unit of time. The third represents an

\footnotetext{
${ }^{1}$ A contribution of the University of Nebraska Agricultural Research Division, Lincoln, Journal Series No. 14598. This research was supported in part by funds provided through the Hatch Act. The authors appreciate an important contribution from an anonymous reviewer.

${ }^{2}$ Corresponding author: mnielsen1@unl.edu

Received August 10, 2005.

Accepted October 17, 2005.
}

improvement in efficiency through reducing overhead of maintenance relative to the cost of making a new unit of production; the first 2 represent improvements in energy efficiency through more efficient physiological processes.

We have reported responses in feed intake following selection for heat loss, as a proxy for energy for maintenance in mice (Nielsen et al., 1997a,b). After 15 generations of selection for high and low heat loss, measured in 9- to 11-wk-old males, feed intake relative to body size $\left(\mathrm{g} \cdot \mathrm{kg}^{-0.75} \cdot \mathrm{d}^{-1}\right)$ changed; low-line mice consumed $81 \%$ of the amount consumed by high-line mice at 8 to $11 \mathrm{wk}$ of age. Intake in the unselected control was intermediate. In addition, we have reported that the lines differ in body composition (Nielsen et al., 1997b); the low heat-loss line was fatter and the high heat-loss line was leaner than the intermediate control. 
Because these selected lines differ in feed intake and to a lesser extent in body composition but do not differ in body size, one would expect the lines to also differ in the cost of maintenance per unit of size or in the cost of lean or fat gain. If these lines of mice differ in the cost of maintenance per body size, but not in the cost of gains, then selection to improve efficiency of livestock would be directed at lowering maintenance cost. However, if these lines have significantly different costs of protein or fat deposition, it could add further ramifications and complications for selection in livestock populations to improve the efficiency of energy use. The objective of this study was to test for differences between these mouse lines in the energy costs for maintenance and gain.

\section{MATERIALS AND METHODS}

\section{Mouse Lines}

Lines supplying the animals used in this study are described in detail by Nielsen et al. (1997a,b). Briefly, there were 3 independent replications of selection for either high (MH), low (ML) heat loss, or an unselected control (MC). This gave 9 unique lines. Selection criterion was heat loss $\left(\mathrm{kcal} \cdot \mathrm{kg}^{-0.75} \cdot \mathrm{d}^{-1}\right)$ measured overnight in direct calorimeters on males only. All lines were derived from the same base population. Within a replicate, there were contemporary $\mathrm{MH}, \mathrm{ML}$, and $\mathrm{MC}$ lines, and the replicates were separated in their life cycle by 5 wk. Generation length was 15 wk.

Selection was practiced for 16 generations. Lines were then maintained with increased population size and no intentional selection until measurement of heat loss and selection for the same criteria in the $\mathrm{MH}, \mathrm{ML}$, and $\mathrm{MC}$ lines were resumed in generation 42. Mice used in this study were from generation 43 and from all 9 lines. Throughout all generations, matings were assigned to minimize inbreeding. When selection ceased at generation 16, heat loss in $\mathrm{MH}$ males averaged 180 $\mathrm{kcal} \cdot \mathrm{kg}^{-0.75} \cdot \mathrm{d}^{-1}$, and heat loss in ML males averaged $110 \mathrm{kcal} \cdot \mathrm{kg}^{-0.75} \cdot \mathrm{d}^{-1}$. At generation 42 , heat loss of $\mathrm{MH}$ males averaged $156 \mathrm{kcal} \cdot \mathrm{kg}^{-0.75} \cdot \mathrm{d}^{-1}$, and heat loss of ML males averaged $110 \mathrm{kcal} \cdot \mathrm{kg}^{-0.75} \cdot \mathrm{d}^{-1}$. Body weight did not differ between MH and ML mice, but at generation 16 feed intake between 8 and 11 wk of age for $\mathrm{MH}$ males was $23 \%$ greater than feed intake of ML males. At generation 42, feed intake of $\mathrm{MH}$ males between 8 and 11 wk of age was $26 \%$ greater than feed intake of ML males, and as in earlier generations, BW between the lines did not differ. All animal research was performed under approval of the University of NebraskaLincoln Institutional Animal Care and Use Committee.

\section{Feed Intake Measurement and Design}

Forty-eight mice from each line ( $\mathrm{MH}, \mathrm{ML}, \mathrm{MC})$, composed of 24 females and 24 males, were used in each of the 3 replicates for this study. Animals were randomly assigned to 3 groups: the ad libitum feeding group, the $80 \%$ ad libitum feeding group, and the $60 \%$ ad libitum feeding group for a 28-d feeding period. The goal of this design with different levels of feed intake was to create a data set with variation in feed intake, BW, and gain for use in a regression analysis. Feeding groups were separated by $1 \mathrm{~d}$ in starting dates. The ad libitum group was started first; then $1 \mathrm{~d}$ later, the $80 \%$ group was started; and $2 \mathrm{~d}$ after the ad libitum group was started, the $60 \%$ group was started. Thus, within each replicate, the ad libitum group was fed from d 0 through 28, and the $60 \%$ of ad libitum group was fed from $d 2$ through 30 of the study period for a replicate. This allowed a built-in safeguard to keep the groups separated and allowed the calculations for assigned feeding levels to be carried out.

All animals were weaned at $19 \mathrm{~d}$ into same-sex litter groups and fed a lactation diet (Harlan Teklad 8626: $20 \% \mathrm{CP}, 10 \%$ crude fat, $4.25 \mathrm{kcal}$ of gross energy/g; Harlan Teklad, Madison, WI) and started in the study when most animals were $\sim 21 \mathrm{~d}$ of age and fed a growing diet (Harlan Teklad 8604: 24\% CP, 4\% crude fat, 3.93 $\mathrm{kcal}$ of gross energy/g, $3.10 \mathrm{kcal}$ of ME/g; Harlan Teklad, Madison, WI) for $28 \mathrm{~d}$. A few animals were 22 or $23 \mathrm{~d}$ old when started. At the starting dates, animals were weighed, anesthetized ( $0.012 \mathrm{mg}$ of Ketamine/g of BW and $0.0004 \mathrm{mg}$ of Xylazine/g of BW administered i.p.), and subjected to dual x-ray densitometry (PIXImus; GE Lunar, Madison, WI) for prediction of body composition.

Animals were then individually caged with access to water at all times. Animals in the ad libitum group were offered powdered diet in special aluminum feeders that minimized spillage. Feed intake was measured every day for the entire study. Animals in both the 60 and $80 \%$ groups were offered pelleted feed in amount calculated for each day based on the feed intake of their respective replicate-line-sex ad libitum group at the same age in the study. At the conclusion of the $28 \mathrm{~d}$ of feeding, mice were euthanized by carbon dioxide asphyxiation, weighed, and the whole bodies were measured by dual x-ray densitometry for prediction of body composition.

Samples of 21-d-old mice $(\mathrm{n}=40)$ and 49 -d-old mice $(\mathrm{n}=60)$ from the 3 feeding levels and across selection lines were taken for chemical determination of fat by ether extraction. Regression adjustment of predictions of body fatness from the dual x-ray data were developed and applied for the 21-d-old mice and for each feeding level of the 49-d-old mice (Eggert, 2004). Correlation between prediction of fat from dual x-ray densitometry and measurement of fat by ether extraction was 0.90 in both 21-d-old and 49-d-old animals. In another small study ( $\mathrm{n}=20$ ) utilizing a crossover design, the amount of intake of the powdered diet was compared with that for the pelleted diet. No difference was found for the amount of intake between the different physical forms of the diet; thus, assigning 60 or $80 \%$ levels of the pelleted diet based on the ad libitum intake of the powdered diet would not be biased. 
Table 1. Numbers of animals in the final data set by replicate, line, sex, and feeding level

\begin{tabular}{|c|c|c|c|c|c|c|}
\hline Replicate & Line $^{1}$ & $\mathrm{Sex}^{2}$ & Ad libitum & $\begin{array}{c}80 \% \\
\text { ad libitum }\end{array}$ & $\begin{array}{c}60 \% \\
\text { ad libitum }\end{array}$ & Total \\
\hline 1 & $\mathrm{MH}$ & $\mathrm{F}$ & 8 & 6 & 6 & 20 \\
\hline 1 & $\mathrm{MC}$ & $\mathrm{F}$ & 8 & 7 & 7 & 22 \\
\hline 1 & ML & $\mathrm{F}$ & 7 & 6 & 6 & 19 \\
\hline 1 & $\mathrm{MH}$ & M & 8 & 7 & 8 & 23 \\
\hline 1 & $\mathrm{MC}$ & M & 8 & 8 & 7 & 23 \\
\hline 1 & ML & M & 8 & 8 & 8 & 24 \\
\hline 2 & MH & $\mathrm{F}$ & 7 & 7 & 4 & 18 \\
\hline 2 & $\mathrm{MC}$ & $\mathrm{F}$ & 8 & 8 & 4 & 20 \\
\hline 2 & ML & $\mathrm{F}$ & 8 & 7 & 8 & 23 \\
\hline 2 & $\mathrm{MH}$ & M & 8 & 8 & 6 & 22 \\
\hline 2 & $\mathrm{MC}$ & M & 7 & 8 & 6 & 21 \\
\hline 2 & ML & M & 8 & 7 & 7 & 22 \\
\hline 3 & $\mathrm{MH}$ & $\mathrm{F}$ & 7 & 8 & 7 & 22 \\
\hline 3 & $\mathrm{MC}$ & $\mathrm{F}$ & 8 & 8 & 5 & 21 \\
\hline 3 & ML & $\mathrm{F}$ & 8 & 8 & 6 & 22 \\
\hline 3 & $\mathrm{MH}$ & M & 8 & 8 & 6 & 22 \\
\hline 3 & $\mathrm{MC}$ & M & 8 & 7 & 4 & 19 \\
\hline 3 & ML & M & 8 & 7 & 8 & 23 \\
\hline
\end{tabular}

${ }^{1} \mathrm{MH}=$ selection for high heat loss; $\mathrm{MC}=$ unselected control; and $\mathrm{ML}=$ selection for low heat loss. ${ }^{2} \mathrm{~F}=$ female and $\mathrm{M}=$ male.

Daily feed intake for ad libitum-fed mice was calculated as the difference between the feed present the previous day and the feed present on the current day of the study. Feed intake was calculated for each individual ad libitum mouse and averaged over the same line and sex in the same replicate (e.g., ML females or $\mathrm{MH}$ males). These daily averages were used to calculate the individual feeding levels for each mouse in the 80 and $60 \%$ restricted groups. To calculate the daily level for each mouse the following equation was used:

$$
\begin{gathered}
\text { Feed level, day } \mathrm{i}= \\
(\text { BWT21/ABWT21) * AFEED, day } \mathrm{i} * \mathrm{Y},
\end{gathered}
$$

in which BWT21 is the BW for the individual mouse at $21 \mathrm{~d}$, ABWT21 is the average BW of the corresponding same sex-line-replicate group of ad libitum mice at $21 \mathrm{~d}$, AFEED is the average feed intake of the corresponding sex-line-replicate group of ad libitum mice for day $\mathrm{i}$, and $\mathrm{Y}$ is 0.8 for a mouse in the $80 \%$ group or 0.6 for the $60 \%$ group. An example would be a ML male mouse assigned to the $60 \%$ group in replicate 2 with a starting weight of $14.6 \mathrm{~g}$. The ad libitum ML male mouse group's average starting weight in replicate 2 was $13.4 \mathrm{~g}$. The average daily feed intake for ad libitum ML male mouse group in replicate 2 was $4.38 \mathrm{~g}$ on d 18. Thus, on $\mathrm{d} 18$, the male mouse in ML on the $60 \%$ feeding level would be given:

$$
(14.6 / 13.4) * 4.38 * 0.6=2.86 \mathrm{~g} \text { of feed. }
$$

This equation was used to calculate all feed levels for all mice in both the 60 and $80 \%$ ad libitum feeding groups in the study during the $28 \mathrm{~d}$ of the study.

\section{Final Data Set}

The full design was to have 24 animals of each sexline-replicate class with one-third ( 8 mice) in each of the feeding groups. Therefore, a total of 432 animals began in the experiment, and 386 animals were in the final data set. Table 1 contains the numbers of mice by replicate-line-sex and feeding group in the final data set. Only one sex-line-replicate group had all 24 animals in the final data set, and the smallest number remaining in a group was 18. Most losses were in the $60 \%$ feeding level. Reasons for the loss of animals were: death loss or euthanasia of morbid animals during the study (20 mice), deletion of records for animals that did not gain at least $1 \mathrm{~g}$ during the $28 \mathrm{~d}$ (15 mice), and deletion of records that had predicted fat composition that was deemed too great or too low based on replicateline-sex cohorts or feed intake recorded that was deemed either too great or too low relative to animal size and growth (11 mice).

\section{Estimation of Energy Costs of Gain and Maintenance}

Total feed intake was calculated by summing the daily intake measurement (feed disappearance) for each animal for the duration of the study. This sum was converted into ME by multiplying the total feed intake (g) by $3.10 \mathrm{kcal} / \mathrm{g}$, the ME value of the feed provided by the feed manufacturer. Three approaches were then used. The first approach was an attempt to partition energy intake between maintenance cost, fat deposition cost, and lean deposition cost by replicate, line, and sex using regression analysis. Coefficients were estimated for these energy costs by replicate, line, and sex and were analyzed as dependent variables to test 
for differences in line, sex, or interaction of line $\times$ sex for these coefficients.

Highly accurate prediction of body composition in 21d-old and 49-d-old animals was difficult and, we suspect, subject to some error. This may have limited the ability of the first approach to partition the costs of lean and fat gain. A second approach was thus used, and this regression analysis yielded estimates of coefficients for maintenance cost and total gain deposition cost. Again, the coefficients were estimated by replicate, line and sex and used as input for analysis of line, sex, or interaction of line $\times$ sex.

The third approach used multiple regression, fitting the entire data to one model. The model was similar to that used in approach I, except the regression on metabolic size for maintenance was nested within replicate-line-sex classes, and the regressions on lean gain and fat gain were pooled for all the data classes. These maintenance coefficients were then analyzed by a mixed model as described for the other 2 models.

The regression models for deriving the energy coefficients for approaches I and II, run for each replicateline-sex class, were:

$$
\begin{gathered}
\text { Approach I: ME intake }(\mathrm{kcal})=\mathrm{b}_{\mathrm{m}}\left(\Sigma \mathrm{BW}^{0.75}\right) \\
+\mathrm{b}_{\mathrm{l}}[\text { lean gain }(\mathrm{g})]+\mathrm{b}_{\mathrm{f}}[\text { fat gain }(\mathrm{g})]+\text { error, and }
\end{gathered}
$$

Approach II: ME intake $(\mathrm{kcal})=\mathrm{b}_{\mathrm{m}}\left(\Sigma \mathrm{BW}^{0.75}\right)$

$$
+b_{g}[\text { total gain }(g)]+\text { error; }
$$

the regression model for deriving energy coefficients for approach III, using the entire data set, was

$$
\begin{gathered}
\text { Approach III: ME intake }(\mathrm{kcal})= \\
\left.\mathrm{b}_{\mathrm{m}}\left(\Sigma \mathrm{BW}^{0.75}\right) \text { \{nested within replicate-line-sex }\right\} \\
+\mathrm{b}_{\mathrm{l}}[\text { lean gain }(\mathrm{g})]+\mathrm{b}_{\mathrm{f}}[\text { fat gain }(\mathrm{g})]+\text { error }
\end{gathered}
$$

in which $b_{m}=$ regression coefficient for the cost of maintenance $\left(\mathrm{kcal} \cdot \mathrm{kg}^{-0.75} \cdot \mathrm{d}^{-1}\right), \mathrm{b}_{1}=$ regression coefficient for the cost of lean deposition $(\mathrm{kcal} / \mathrm{g}), \mathrm{b}_{\mathrm{f}}=$ regression coefficient for the cost of fat deposition $(\mathrm{kcal} / \mathrm{g}), \mathrm{b}_{\mathrm{g}}=$ regression coefficient for the cost of gain $(\mathrm{kcal} / \mathrm{g})$; and

$$
\left(\Sigma \mathrm{BW}^{0.75}\right)=\text { integral of daily metabolic } \mathrm{BW}(\mathrm{kg})=
$$$$
\left\{(1.75 * \mathrm{ADG})^{-1}\right\}^{*}\left\{(\mathrm{BW} 0+28 * \mathrm{ADG})^{1.75}-\mathrm{BW}^{1.75}\right\},
$$

in which BW0 = weight at $21 \mathrm{~d}$ and $\mathrm{ADG}=$ average daily gain over the 28-d period. Preliminary analyses showed that use of $\mathrm{BW}^{0.75}$ explained slightly more variation than simply BW as a definition of body size for maintenance.

The REG procedure of SAS (SAS Inst., Inc., Cary, NC) was used for the regression steps of approaches I and II, and the GLM procedure was used for approach III. The mixed-model procedure of SAS was used to analyze the variation in each coefficient $\left(b_{m}, b_{l}, b_{f}\right.$, or $b_{g}$ ) derived in approaches I, II, and III in terms of effects of sex, line, and sex $\times$ line interaction. The effect of replicate was considered random, and the other effects were considered fixed. Orthogonal contrasts were used to partition the effects of the lines into 1) effect of selection using the contrast $\mathrm{MH}-\mathrm{ML}$ and 2) asymmetry of the response using the contrast $(\mathrm{MH}+\mathrm{ML}) / 2-\mathrm{MC}$.

\section{RESULTS}

\section{Approach I: Simultaneous Estimation of Cost of Lean Gain, Fat Gain and Maintenance}

Maintenance Coefficient. Regressions coefficients for maintenance, lean gain, and fat gain are shown in Table 2. Levels of statistical significance for line, sex and line by sex tests for the various energy coefficients are presented in Table 3. Maintenance coefficient average for the MC line was $204.5 \pm 8.9 \mathrm{kcal} \cdot \mathrm{kg}^{-0.75} \cdot \mathrm{d}^{-1}$, and averages for the MH and ML lines were $193.8 \pm 8.9$ and $181.4 \pm 8.9 \mathrm{kcal} \cdot \mathrm{kg}^{-0.75} \cdot \mathrm{d}^{-1}$, respectively. Males had an average maintenance cost of $190.3 \pm 7.1 \mathrm{kcal} \cdot \mathrm{kg}^{-0.75} \cdot \mathrm{d}^{-}$ ${ }^{1}$, and females had an average cost of $195.6 \pm 7.1 \mathrm{kcal} \cdot \mathrm{kg}^{-}$ ${ }^{0.75} \cdot \mathrm{d}^{-1}$. No differences were found between the $\mathrm{MH}$ and $\mathrm{ML}$ lines in $\mathrm{b}_{\mathrm{m}}$. In addition, no evidence for asymmetry of selection was found. Males and females were not different in the estimated maintenance coefficients. No sex $\times$ line interaction existed.

Lean Cost Coefficient. The lean deposition cost average for the MC line was $8.86 \pm 1.50 \mathrm{kcal} / \mathrm{g}$; the $\mathrm{b}_{1}$ averages for the $\mathrm{MH}$ and ML lines were $11.52 \pm 1.50$ and $8.98 \pm 1.50 \mathrm{kcal} / \mathrm{g}$, respectively. Males had an average lean gain cost of $9.60 \pm 1.24 \mathrm{kcal} / \mathrm{g}$, and females had an average cost of $9.97 \pm 1.24 \mathrm{kcal} / \mathrm{g}$. No difference between the MH and ML lines was found for $b_{1}$. No evidence of asymmetry of selection was found, nor was there any difference between males and females. There was no sex $\times$ line interaction.

Fat Cost Coefficient. Average fat deposition cost for the MC line was $16.94 \pm 6.74 \mathrm{kcal} / \mathrm{g}$. Fat gain cost averages for the $\mathrm{MH}$ and $\mathrm{ML}$ lines were $6.43 \pm 6.74$ and $14.02 \pm 6.74 \mathrm{kcal} / \mathrm{g}$, respectively. No difference was found between the MH and ML lines. Additionally, no asymmetry of selection was found for $b_{f}$. A significant difference was found comparing the sexes $(P=0.02)$. Females required $22.73 \pm 5.58 \mathrm{kcal} / \mathrm{g}$, and males used only $2.19 \pm 5.58 \mathrm{kcal} / \mathrm{g}$ for $\mathrm{b}_{\mathrm{f}}$. The magnitude of this difference is extremely large and is probably suspect. But, females do appear to have greater energy requirements for at least some component of gain as will be shown in analysis II, and it appears to be present in the cost of fat gain. No sex $\times$ line interaction was found.

\section{Approach II: Simultaneous Estimation of Cost of Total Gain and Maintenance}

Maintenance Coefficient. Table 2 contains the regression coefficients for maintenance and total gain, 
Table 2. Estimates of energy coefficients by 3 analyses ${ }^{1}$

\begin{tabular}{|c|c|c|c|c|c|c|c|c|}
\hline \multirow[b]{2}{*}{ Rep } & \multirow[b]{2}{*}{ Line $^{2}$} & \multirow[b]{2}{*}{$\mathrm{Sex}^{3}$} & \multicolumn{3}{|c|}{ Approach I } & \multicolumn{2}{|c|}{ Approach II } & \multirow{2}{*}{$\frac{\text { Approach II }}{b_{\mathrm{m}}}$} \\
\hline & & & $\mathrm{b}_{\mathrm{m}}{ }^{4}$ & $\mathrm{~b}_{1}{ }^{4}$ & $b_{f}^{4}$ & $\mathrm{~b}_{\mathrm{m}}$ & $\mathrm{b}_{\mathrm{g}}{ }^{4}$ & \\
\hline 1 & $\mathrm{MC}$ & $\mathrm{F}$ & 168.9 & 13.74 & 11.43 & 170.7 & 13.44 & 190.3 \\
\hline 1 & MH & $\mathrm{F}$ & 183.2 & 13.85 & 15.97 & 181.4 & 14.07 & 207.8 \\
\hline 1 & ML & $\mathrm{F}$ & 168.9 & 11.00 & 23.54 & 160.0 & 13.38 & 179.0 \\
\hline 1 & $\mathrm{MC}$ & M & 193.8 & 10.80 & -7.70 & 197.4 & 9.03 & 189.4 \\
\hline 1 & MH & M & 195.6 & 9.32 & 20.13 & 183.2 & 10.91 & 189.4 \\
\hline 1 & ML & M & 188.5 & 8.76 & 1.95 & 192.1 & 7.67 & 177.6 \\
\hline 2 & $\mathrm{MC}$ & $\mathrm{F}$ & 227.6 & 3.05 & 38.19 & 200.9 & 11.84 & 197.7 \\
\hline 2 & MH & $\mathrm{F}$ & 220.5 & 6.26 & 32.10 & 192.1 & 12.21 & 203.2 \\
\hline 2 & ML & $\mathrm{F}$ & 186.7 & 6.28 & 50.24 & 160.0 & 9.56 & 178.5 \\
\hline 2 & $\mathrm{MC}$ & M & 206.3 & 7.45 & 20.59 & 195.6 & 12.17 & 191.4 \\
\hline 2 & $\mathrm{MH}$ & M & 154.7 & 16.41 & -10.02 & 176.0 & 7.15 & 188.3 \\
\hline 2 & ML & M & 161.8 & 9.47 & -9.67 & 168.9 & 7.15 & 148.7 \\
\hline 3 & $\mathrm{MC}$ & $\mathrm{F}$ & 217.0 & 10.81 & 27.33 & 202.7 & 13.64 & 219.8 \\
\hline 3 & MH & $\mathrm{F}$ & 204.5 & 13.96 & -4.27 & 213.4 & 12.06 & 223.6 \\
\hline 3 & ML & $\mathrm{F}$ & 190.3 & 10.54 & 10.08 & 190.3 & 10.40 & 192.9 \\
\hline 3 & $\mathrm{MC}$ & M & 213.4 & 7.10 & 11.82 & 208.1 & 8.07 & 196.6 \\
\hline 3 & $\mathrm{MH}$ & M & 211.6 & 9.30 & -15.35 & 211.6 & 6.46 & 201.7 \\
\hline 3 & $\mathrm{ML}$ & $\mathrm{M}$ & 192.1 & 7.83 & 7.95 & 190.3 & 7.86 & 176.8 \\
\hline
\end{tabular}

\footnotetext{
${ }^{1}$ Approach I simultaneously estimated maintenance, fat, and lean gain costs; approach II simultaneously estimated maintenance and total gain costs; and approach III used pooled regression for fat and lean costs and simultaneously estimated maintenance costs.

${ }^{2} \mathrm{MH}=$ selection for high heat loss, $\mathrm{MC}=$ unselected control, $\mathrm{ML}=$ selection for low heat loss.

${ }^{3} \mathrm{~F}=$ female and $\mathrm{M}=$ male.

${ }^{4} \mathrm{~b}_{\mathrm{m}}=$ maintenance regression coefficient $\left(\mathrm{kcal} \cdot \mathrm{kg}^{-0.75} \cdot \mathrm{d}^{-1}\right), \mathrm{b}_{\mathrm{l}}=$ lean cost regression coefficient $(\mathrm{kcal} / \mathrm{g}), \mathrm{b}_{\mathrm{f}}=$ fat cost regression coefficient $(\mathrm{kcal} / \mathrm{g})$, and $\mathrm{b}_{\mathrm{g}}=$ total gain regression coefficient $(\mathrm{kcal} / \mathrm{g})$.
}

Table 3. Summary of probability levels for tests of significance for energy cost estimates ${ }^{1}$

\begin{tabular}{|c|c|c|c|c|}
\hline & \multicolumn{4}{|c|}{ Variable $^{2}$} \\
\hline & $\mathrm{b}_{\mathrm{m}}$ & $b_{1}$ & $b_{f}$ & $b_{g}$ \\
\hline \multicolumn{5}{|l|}{ Approach I } \\
\hline \multicolumn{5}{|l|}{ Line $^{3}$} \\
\hline $\mathrm{MH}-\mathrm{ML}$ & 0.26 & 0.25 & 0.43 & \\
\hline$[(\mathrm{MH}+\mathrm{ML}) / 2]-\mathrm{MC}$ & 0.21 & 0.48 & 0.42 & \\
\hline Sex & 0.55 & 0.84 & 0.02 & \\
\hline Line $\times$ sex & 0.77 & 0.96 & 0.79 & \\
\hline \multicolumn{5}{|l|}{ Approach II } \\
\hline \multicolumn{5}{|l|}{ Line $^{3}$} \\
\hline MH - ML & 0.03 & & & 0.05 \\
\hline$[(\mathrm{MH}+\mathrm{ML}) / 2]-\mathrm{MC}$ & 0.06 & & & 0.87 \\
\hline Sex & 0.26 & & & 0.001 \\
\hline Line $\times$ sex & 0.31 & & & 0.41 \\
\hline \multicolumn{5}{|l|}{ Approach III } \\
\hline \multicolumn{5}{|l|}{ Line $^{3}$} \\
\hline $\mathrm{MH}-\mathrm{ML}$ & 0.01 & & & \\
\hline$[(\mathrm{MH}+\mathrm{ML}) / 2]-\mathrm{MC}$ & 0.17 & & & \\
\hline Sex & 0.10 & & & \\
\hline Line $\times$ sex & 0.53 & & & \\
\hline
\end{tabular}

${ }^{1}$ Approach I simultaneously estimated maintenance, fat, and lean gain costs; approach II simultaneously estimated maintenance and total gain costs; and approach III used pooled regression for fat and lean costs and simultaneously estimated maintenance costs.

${ }^{2} \mathrm{~b}_{\mathrm{m}}=$ maintenance cost, $\mathrm{kcal} \cdot \mathrm{kg}^{-0.75} \cdot \mathrm{d}^{-1} ; \mathrm{b}_{\mathrm{l}}=$ lean gain cost, $\mathrm{kcal} /$ $\mathrm{g} ; \mathrm{b}_{\mathrm{f}}=$ fat gain cost, $\mathrm{kcal} / \mathrm{g}$; and $\mathrm{b}_{\mathrm{g}}=$ total gain cost, $\mathrm{kcal} / \mathrm{g}$.

${ }^{3}$ Linear contrasts of the line effects: $\mathrm{MH}=$ selection for high heat loss, $\mathrm{MC}=$ unselected control, and $\mathrm{ML}=$ selection for low heat loss. and levels of significance for the various tests of line and sex effects are shown in Table 3. Average cost of maintenance for the MC line was $195.6 \pm 8.9 \mathrm{kcal} \cdot \mathrm{kg}^{-}$ ${ }^{0.75} \cdot \mathrm{d}^{-1}$, and averages for the MH and ML lines were $192.1 \pm 8.9$ and $177.8 \pm 8.9 \mathrm{kcal} \cdot \mathrm{kg}^{-0.75} \cdot \mathrm{d}^{-1}$, respectively. Males had an average maintenance cost of $192.1 \pm 7.1$ $\mathrm{kcal} \cdot \mathrm{kg}^{-0.75} \cdot \mathrm{d}^{-1}$, and females had an average of $184.9 \pm$ $7.1 \mathrm{kcal} \cdot \mathrm{kg}^{-0.75} \cdot \mathrm{d}^{-1}$. Estimated maintenance coefficient was significantly different between the $\mathrm{MH}$ and $\mathrm{ML}$ lines $(P<0.03)$. Animals in the $\mathrm{MH}$ line required 16.0 $\mathrm{kcal} \cdot \mathrm{kg}^{-0.75} \cdot \mathrm{d}^{-1}$ more $(9 \%)$ for maintenance of a given size than animals in the ML line. There was evidence for asymmetry of selection $(P=0.06)$; mean maintenance coefficient of the MC line was more similar to that of the $\mathrm{MH}$ than to an intermediate value between the 2 selection lines. No difference $(P=0.26)$ was found between sexes for $b_{\mathrm{m}}$. No sex $\times$ line interaction was found $(P=0.31)$.

Total Gain Cost Coefficient. Gain cost average for the $\mathrm{MC}$ line was $11.56 \pm 0.62 \mathrm{kcal} / \mathrm{g}$. Averages for the $\mathrm{MH}$ and ML lines were $11.58 \pm 0.62$ and $9.79 \pm 0.62$ $\mathrm{kcal} / \mathrm{g}$, respectively. Males had an average gain cost of $8.99 \pm 0.52 \mathrm{kcal} / \mathrm{g}$, and females had an average of 12.31 $\pm 0.52 \mathrm{kcal} / \mathrm{g}$. Comparisons between the $\mathrm{MH}$ and $\mathrm{ML}$ lines for $b_{\mathrm{g}}$ revealed a change due to selection $(P=0.05)$. No evidence of asymmetry of selection was found. A significant difference was found between males and females $(P<0.001)$; females required $12.31 \mathrm{kcal} / \mathrm{g}$, whereas males required $8.99 \mathrm{kcal} / \mathrm{g}$ to gain weight. This difference of $3.32 \mathrm{kcal} / \mathrm{g}$ supports the results in approach I that sexes differed for at least one component 
of gain (fat) with females requiring a greater amount of energy per gram of gain than males. No sex $\times$ line interactions were found.

Mice of the MH line required more energy for maintenance. Previous experiments measuring heat loss between $\mathrm{MH}, \mathrm{MC}$, and $\mathrm{ML}$ male mice showed the $\mathrm{MH}$ males averaged $180 \mathrm{kcal} \cdot \mathrm{kg}^{-0.75} \cdot \mathrm{d}^{-1}$ and ML males averaged $110 \mathrm{kcal} \cdot \mathrm{kg}^{-0.75} \cdot \mathrm{d}^{-1}$ when selection ceased at generation 16. Even though the lines had been maintained for 26 generations with no selection, at generation 42 , the heat loss of $\mathrm{MH}$ males averaged $156 \mathrm{kcal} \cdot \mathrm{kg}^{-0.75} \cdot \mathrm{d}^{-}$ ${ }^{1}$, and ML males averaged $110 \mathrm{kcal} \cdot \mathrm{kg}^{-0.75} \cdot \mathrm{d}^{-1}$. Because part of heat loss results from maintenance, and the $\mathrm{MH}$ line has a greater average heat loss than the ML line, it is not surprising to find the $\mathrm{MH}$ animals requiring more energy for maintenance than the ML animals.

\section{Approach III: Estimating Maintenance Coefficients with Average Costs of Gains Across Classes}

Estimates of maintenance coefficients are listed in Table 2, and levels of significance of tests of line and sex effects are provided in Table 3. Average estimates revealed $\mathrm{MH}$ mice required $202.3 \pm 5.3$; $\mathrm{MC}$ mice required $195.6 \pm 5.1$; and $\mathrm{ML}$ animals required $174.1 \pm$ $5.6 \mathrm{kcal} \cdot \mathrm{kg}^{-0.75} \cdot \mathrm{d}^{-1}$ for $\mathrm{b}_{\mathrm{m}}$. As expected, these rank the same as the heat loss data at generations 42 . Strong evidence for a selection response difference $(P<0.01)$ was found when comparing $\mathrm{MH}$ and ML lines for $\mathrm{b}_{\mathrm{m}}$. Animals of the MH line used $28.2 \mathrm{kcal} \cdot \mathrm{kg}^{-0.75} \cdot \mathrm{d}^{-1}$ more (16\%) energy than animals of the ML line for maintenance of a fixed size. Asymmetry of selection effect on maintenance coefficient was not evident $(P=0.17)$. The common regressions for cost of lean gain and for fat gain were 10.0 and $11.5 \mathrm{kcal} / \mathrm{g}$, respectively.

Sex was also found to have some effect on $b_{m}$. Females required $196.9 \pm 4.9 \mathrm{kcal} \cdot \mathrm{kg}^{-0.75} \cdot \mathrm{d}^{-1}$ whereas males required $184.4 \pm 4.8 \mathrm{kcal} \cdot \mathrm{kg}^{-0.75} \cdot \mathrm{d}^{-1}$, or females were $7 \%$ greater in energy for maintenance $(P=0.10)$. No sex $\times$ line interaction was found.

\section{DISCUSSION}

Average values using approach $\mathrm{I}$ for $\mathrm{b}_{\mathrm{m}}$ ranged from 181.4 for the ML line to $204.5 \mathrm{kcal} \cdot \mathrm{kg}^{-0.75} \cdot \mathrm{d}^{-1}$ for the $\mathrm{MC}$ line. One would expect animals in the $\mathrm{MC}$ line to be intermediate to the ML and the MH lines maintenance cost levels; instead, estimated energy adjusted for body size in the MC line was greater than the $\mathrm{MH}$ line. These estimates were large compared with estimates in mice by Canolty and Koong (1976): $176 \mathrm{kcal} \cdot-$ $\mathrm{kg}^{-0.75} \cdot \mathrm{d}^{-1}$; and Bernier et al. (1986): 154 to $164 \mathrm{kcal} \cdot \mathrm{kg}^{-}$ $0.75 \cdot \mathrm{d}^{-1}$; and in pigs by Rao and McCracken (1991): 146 $\mathrm{kcal} \cdot \mathrm{kg}^{-0.75} \cdot \mathrm{d}^{-1}$. But, estimates of maintenance costs derived in approach I were similar in magnitude to the estimates reported for pigs by Van Milgen and Noblet (1999): 182 to $216 \mathrm{kcal} \cdot \mathrm{kg}^{-0.75} \cdot \mathrm{d}^{-1}$.

Literature values for $b_{f}$, reported in the rat by Pullar and Webster (1977), range from 11.3 to $13.7 \mathrm{kcal} / \mathrm{g}$; Tess et al. (1984) reported estimates in the pig of 16.1 to $16.2 \mathrm{kcal} / \mathrm{g}$. Estimated costs for $\mathrm{b}_{\mathrm{f}}$ from approach I were more variable at $16.94,6.43$, and $14.02 \mathrm{kcal} / \mathrm{g}$ for the MC, MH, and ML lines, respectively. The values for the MC and ML lines were greater than expected, and the value for the $\mathrm{MH}$ line was less than expected. The pooled regression used in approach III yielded an estimated cost of fat deposition of $11.5 \mathrm{kcal} / \mathrm{g}$, which was within the range reported by Pullar and Webster (1977).

There was a wide range of $b_{f}$ values between lines using approach I. In fact, some coefficient estimates were negative, and others were 3 times greater in magnitude than might be anticipated. With limited numbers and the positive correlations among the independent variables (the pooled within replicate-line-sex correlations were $0.75,0.51$, and 0.66 for sum of $\mathrm{BW}^{0.75}$ with lean gain, sum $\mathrm{BW}^{0.75}$ with fat gain, and lean gain with fat gain, respectively), this can and does occur. With negative estimates of cost of fat gain in a replicateline-sex subclass, estimates of maintenance and/or lean gain cost would be overestimated. Likewise, large positive estimated costs of fat gain would be associated with concomitant lower estimates of one or both of the other 2 energy costs. It might be expected the ML line would lay fat down more efficiently than the MC line or the $\mathrm{MH}$ line. However, approach I produced estimates for the $\mathrm{MH}$ line of nonsignificantly lower average energy cost $(6.43 \mathrm{kcal} / \mathrm{g})$ than the ML (14.02) or the MC line (16.94) in fat deposition.

Literature values for cost of protein deposition reported in Pullar and Webster (1977) range from 7.5 to $15.8 \mathrm{kcal} / \mathrm{g}$. Tess et al. (1984) reported estimates ranging from 10.1 to $11.1 \mathrm{kcal} / \mathrm{g}$ in the pig. From approach $\mathrm{I}$, the $\mathrm{MH}$ line had an estimated $\mathrm{b}_{1}$ value of $11.52 \mathrm{kcal} /$ $\mathrm{g}$, whereas the MC and ML lines had lesser but quite consistent values of 8.86 and $8.98 \mathrm{kcal} / \mathrm{g}$, respectively. When $b_{1}$ is converted to $b_{\text {protein }}$ (i.e., division by 0.25 to account for water content of lean), these values then become $46.08,35.44$, and $35.92 \mathrm{kcal} / \mathrm{g}$ for the $\mathrm{MH}, \mathrm{MC}$, and ML lines, respectively. These values were not within the range of the literature values previously cited. The pooled estimate for lean gain obtained in approach III of $10.0 \mathrm{kcal} / \mathrm{g}$ converts to $40 \mathrm{kcal} / \mathrm{g}$ on a protein basis and is thus greater than literature estimates.

Partitioning between fat and protein cost of gain is difficult because the amount of gain in each component and BW are positively correlated, and our ability to determine body composition for an animal was probably not accurate. We estimated the correlation between the dual x-ray prediction and ether extract to be 0.90 , and we relied on adjusted dual x-ray prediction for all our estimates of body composition given that was our method to predict initial body composition at the start of measurement of feed consumption. Even small errors in prediction of body lean and fat have large impact on estimation of energy cost of lean and fat deposition. In addition to believing that we were not very successful in estimating the costs for lean and fat gain for these 
lines, we also suspect that our ranking of $b_{m}$ estimates in approach I for $\mathrm{MC}>\mathrm{MH}$ is biased due to the method, given our many other measurements of feed intake (Nielsen et al., 1997a and other data sets not reported yet) in which we find estimated maintenance cost per unit of size for the lines in order MH $>$ MC $>$ ML.

Approach II partitioned between maintenance cost and total gain cost. Given the difficulty in predicting body composition, and if differences in compositional percentages are not great, then estimating a single cost of gain may be a more robust method for detecting possible line differences. The $b_{m}$ average values derived in approach II for MC, MH, and ML mice were 195.6, 192.1 , and $177.8 \mathrm{kcal} \cdot \mathrm{kg}^{-0.75} \cdot \mathrm{d}^{-1}$, respectively. Mice of the $\mathrm{MH}$ line had greater estimated maintenance cost per unit size than the ML line, but again the estimate for MC was not intermediate to the other lines. We believe that the results of approach II are more representative of differences between the lines in energy use, yet the fact that the estimated maintenance coefficient of the $\mathrm{MC}$ was still greater than that in the $\mathrm{MH}$ raises questions. These values were slightly different from the values in approach I but still were within the range of estimates given by Van Milgen and Noblet (1999) in pigs. Costs of gain were 11.56, 11.58, and $9.79 \mathrm{kcal} / \mathrm{g}$ for the MC, MH, and ML lines, respectively. These values for $b_{g}$ were intermediate to the values presented for $b_{f}$ and $b_{1}$ for each respective line in analysis I. Males had lower estimated cost of gain when compared with females.

Approach III used pooled regression across classes to estimate average costs per unit of fat and lean gain. Thus, it assumed that these costs were the same for lines and sexes. The estimated $b_{m}$ values for the MC, $\mathrm{MH}$, and ML lines were 195.6, 202.3, and $174.1 \mathrm{kcal}$. $\mathrm{kg}^{-0.75} \cdot \mathrm{d}^{-1}$, respectively. Orthogonal contrasts between the MH vs. ML lines revealed the effect of selection $(P$ $<0.01)$ and little evidence of asymmetry of response $(P=0.17)$. Differences between sexes were evident $(P$ $<0.10$ ); females required about $7 \%$ more energy to maintain the same BW. Given the doubts about our ability to estimate costs of component gains in approach I and the slightly greater estimate of $b_{m}$ for MC relative to $\mathrm{MH}$ in approach II, we suspect that the comparisons of the lines for the maintenance coefficient are most accurate for approach III, in which we depended on common costs of lean and fat gains across all lines and sexes.

We conclude that selection has changed energy requirement for maintenance per unit of body size. In addition, females have greater energy requirement for maintenance of a given body size than do males. Evidence is not strong that selection has changed energy cost for gain, and perhaps fortunately from the stand- point of an applied selection program, data from approach II suggest that if selection has had an effect on cost for gain, it is correlated positively with change in maintenance. Thus selection applied to decrease cost of maintenance per unit body size would also decrease the energy cost per unit of gain, if variation in this component exists. Evidence is also present that, after accounting for maintenance, greater energy is required per unit of gain in females than in males.

\section{IMPLICATIONS}

If selection had changed the cost of maintenance as well as that of gain, then these would need to be considered in any livestock selection program aimed at improving the efficiency of feed use. Evidence is strong that selection has changed the energy cost per unit body size for maintenance, and substantial genetic variation exists in this component for selection to be effective. There is not strong evidence that selection has changed the partial energy cost per unit of gain. Thus selection programs aimed at improving efficiency should be able to concentrate on reducing energy costs of maintenance per unit body size, increasing product output per unit of time, or both.

\section{LITERATURE CITED}

Bernier, J. F., C. C. Calvert, T. R. Famula, and R. L. Baldwin. 1986. Maintenance energy requirement and net energetic efficiency in mice with a major gene for rapid postweaning gain. J. Nutr. 116:419-428.

Canolty, N. L., and L. J. Koong. 1976. Utilization of energy for maintenance and for fat and lean gains by mice selected for rapid postweaning growth rate. J. Nutr. 106:1202-1208.

Eggert, D. L. 2004. Costs of lean deposition, fat deposition and maintenance in three lines of mice selected for heat loss. MS Thesis. Univ. Nebraska, Lincoln.

Nielsen, M. K., B. A. Freking, L. D. Jones, S. M. Nelson, T. L. Vorderstrasse, and B. A. Hussey. 1997a. Divergent selection for heat loss in mice: II. Correlated responses in feed intake, body mass, body composition, and number born through fifteen generations. J. Anim. Sci. 75:1469-1476.

Nielsen, M. K., L. D. Jones, B. A. Freking, and J. E. DeShazer. 1997b. Divergent selection for heat loss in mice: I. Selection applied and direct response through fifteen generations. J. Anim. Sci. 75:1461-1468.

Pullar, J. D., and J. F. Webster. 1977. The energy cost of fat and protein deposition in the rat. Br. J. Nutr. 37:355-363.

Rao, D. S., and K. J. McCracken. 1991. Effect of energy intake on protein and energy metabolism of boars of high genetic potential for lean growth. Anim. Prod. 52:499-507.

Tess, M. W., G. E. Dickerson, J. A. Nienaber, J. T. Yen, and C. L. Ferrell. 1984. Energy costs of protein and fat deposition in pigs fed ad libitum. J. Anim. Sci. 58:111-122.

Van Milgen, J., and J. Noblet. 1999. Energy partitioning in growing pigs: The use of a multivariate model as an alternative for factorial analysis. J. Anim. Sci. 77:2154-2162. 